\title{
Rebranding strategy PT.Indonesia Building Solutions Plant Cilacap in forming brand awareness
}

\author{
Hani Fatkhur Rohmah ${ }^{\text {a,1,* : a,2 }}$ Choirul Fajri, S.I.Kom., M.A \\ ${ }^{a}$ Communications Science Ahmad Dahlan University, Jl. Ringroad Selatan, Kragilan, Tamanan, Kec. Banguntapan, Bantul, Daerah Istimewa Yogyakarta \\ 55191 \\ ${ }^{1}$ hanifatkhur08@gmail.com*; ${ }^{2}$ choirul.fajri@comm.uad.ac.id \\ * corresponding author
}

Article history

Received 09-11-2021

Revised 10-11-2021

Accepted 11-11-2021

Keywords

Business

Rebranding Strategy

Brand Awareness

\begin{abstract}
The business world is increasingly showing developments with many new business actors appearing both on a small and large scale. The emergence of new business actors certainly has tightened business competition in the market so that it is not uncommon for businesses to close down because they do not have creative strategies to be able to compete. Rebranding is one of the strategies undertaken by business people to maintain their business. There are several factors that cause rebranding, such as changes in ownership, a brand that is starting to be forgotten, to a bad image in the eyes of the public, etc. Rebranding is tantamount to reshaping its brand awareness or public awareness of a new brand. PT. Indonesia Building Solutions is one of the companies that rebranded as a result of the acquisition by Semen Indonesia Group (SIG) of Holcim in January 2019. The acquisition process was followed by a change in all identities starting from the brand name, namely PT. Indonesia Building Solutions and the product name is dynamix. This research was conducted to determine how the rebranding strategy carried out by PT. SBI in forming brand awareness. The method used is descriptive qualitative by conducting direct research through interviews with related parties, documentation, field observations, and supporting data from the internet. Based on the research that has been done, PT. Indonesia Building Solutions rebranded with several stages, namely Repositioning, Renaming, Redesaigning, and Relaunching. With the implementation of these four stages, PT. Indonesia Building Solutions has achieved brand awareness at the brand recognition stage where there are still two more stages to be able to reach top of mind. The title of the research conducted by researchers is "The Rebranding Strategy of PT. Indonesia Building Solutions in Forming Brand Awareness ".
\end{abstract}

This is an open access article under the CC-BY-SA license.

\section{Introduction}

The rapid development of technology makes it easier for humans to do many things. In the business world, technological developments can make it easier for business people to introduce their products (Davis, Yen, Yen, \& Davis, 2020). In Indonesia every year there are always new businesses, both small and large scale businesses. The number of businesses that have sprung up makes every business must have a distinctive feature in the form of a name or logo that can be used as a brand for the business itself. Brand according to Kotler \& Keller (2016) is a sign, symbol, design, or combination that is characteristic of a business that differentiates it from competitors' businesses. The brand also acts as a corporate identity that must be created through a special design that includes unique or distinctive things about the company which will then be used as the company 
logo itself. Introducing a company to have an existence is one of the important tasks for a public relations person in order to create brand awareness among the public about his company.

Judging from its history, PT. Indonesia Building Solutions has changed ownership quite often, this of course also affects their brand changes, both in name and logo (Trott \& Olson, 2009). When it was still Holcim cement, which was marketed by the company, it had the same product name as the company's brand, namely "Holcim cement", the product of this company was also widely known, because PT. Holcim is one of the largest cement companies in the world according to Warta Ekonomi.co.id. However, when it changed to PT. Indonesia Building Solutions, the name of the product being sold is no longer the same as the name of the existing brand, currently PT. Indonesia Building Solutions sells its products under the name "dynamix" (Ulitsky, Shkumatava, Jan, Sive, \& Bartel, 2011). The difference between the brand name and the product name that was recently launched, of course, can cause problems for the company, one of which is that trust in product quality can be doubted because consumers do not recognize the new brand, therefore Public Relations of PT. SBI must have the right strategy in rebranding so that PT. Indonesia Building Solutions can create brand awareness so that people continue to believe in the quality of its products (Thibodeau, Hertig, \& Barnett, 2010).

Based on this, the researcher's problem formulation in this research is how the strategy of PT. Indonesia Building Solutions building brand awareness. The purpose of this research was to find out how the strategy was carried out, what changes occurred in the rebrandng process, and what were the factors experienced during the rebranding process of PT. Indonesia Building Solutions.

\section{Theorotocal Framework}

\section{A. Communications}

Communication is the most important aspect of life, especially for humans. As a social human being, communication is a primary need that cannot be separated from everyday life. Communication is not only in the form of speech conveyed by mouth, but communication also consists of various kinds such as writing which is commonly known as verbal communication and there is also communication through body movements or what is often known as body language (Brenner \& Igamberdiev, 2021).

According to Cangara (2002) Communication is the process of delivering messages from communicators to communicants through the media. In the communication process, errors or obstacles may occur due to misunderstanding between the communicant and the communicator (human error) or due to errors in the media used.

\section{B. Public Relations}

Public Relations (PR) is a form of management in a company or institution that controls public opinion in order to generate a good perception or image. Basically, everyone has become their own homework, as a social human being, of course they want to be seen well by their environment, therefore humans often take actions that can create a good impression for themselves in the eyes of others (Nulhusna, Sandhyaduhita, Hidayanto, \& Phusavat, 2017).

In general, a PR in company has a role to maintain good relations between the company and the public. Apart from maintaining good relations, a PR also has to perform other roles, namely being a communicator of the company, building relationships with the public, back up management, and a good image maker (Peluso \& Blay, 2009). In achieving the goals of his role According to Walker (1985) a PR must carry out the following activities: 1. Build internal relationships (Before a PR builds good external public relations, PR must first build a good relationship between the company and the company. employees or their internal public) (Mishra, Boynton, \& Mishra, 2014), 2. Publicity (a PR conducts publicity with the aim of increasing the existence of his company, with publicity the company will be more widely known to the public) 3 . Press agentry (Creating events or activities that have news value to attract mass media attention and get attention public) 4 . Public affairs (building and maintaining relationships between the government and local communities in order to influence public policy) (Korkmaz Özcan, 2016), 5. Investor relations (building and maintaining mutually beneficial relationships between stakeholders and other parties in order to 
maximize market value) 6. Lobbying (activities PR that has a function follow the policies of the government and local communities) 7. Issue management (proactive process in anticipating, identifying, evaluating, and responding to public issues that affect the organization's relationship with their public).

\section{Marketing Public Relations}

Marketing public relations is often referred to as marketing communication, which is a division that not only markets products but introduces the brand of the company concerned so that it can be known to the public which can have an effect on increasing product sales. According to Tjiptono \& Fandy (2015) Marketing communication is a marketing activity that disseminates information to influence or persuade and remind target markets and companies and their products to be willing to accept, buy and be loyal to the products offered by the company concerned.

Marketing public relations contained in a company has a role that is more than just publicity, such as: 1. Supporting product launches. 2. Helping product repositioning. 3. Popularize certain product categories. 4. Influencing certain target groups. 5. Defend a product that is in trouble. 6. Build a company image (Nunan \& Di Domenico, 2019).

\section{Branding}

Branding basically comes from the word brand which is a company identity in the form of a name which is then visualized into a logo. According to Kotler Philip (2002) version of The American Marketing Association (AMMA) defines a brand as "a tern name, symbol, design, or a combination of these, which is meant to identify a product or service from a person or group of salespeople to differentiate it from competitors.

Meanwhile, according to Iannuzzi (2000) Branding is a business process in choosing what promises, values, and components an entity will have. Conducting a branding has several objectives, namely: 1. Build Awareness (build awareness of the brand) 2. Create an emotional connection (create an emotional connection) 3. Convey distinguishing attributes (convey different attributes) 4. Gain credibility and trust (gain credibility and trust) 5. Achieve buyer preference (meet buyer preferences).

\section{E. Rebranding}

According to Rahman \& Lambkin (2015) the word rebranding comes from the word re and brand, re is a prefix for a verb which sometimes means "again" or "blending" which means the job is done a second time, while the word brand, refers to the definition of The American Marketing Association, namely "the name, term, symbol, design or a combination thereof that identifies the sellers of goods and services with one another to distinguish them from their competitors." The existence of the rebranding process can cause negative risks such as reduced brand existence, changed positive image of the previous brand, decreased company turnover, and many other risks that can be experienced by a brand (Collange, 2015). There are several reasons the motives for a company to rebrand, these motives include: (1) There is a restructuring of the organization / company in order to make a refresher and start a new beginning. (2) Recovery from a crisis experienced by the company / organization. (3) There was a marger or an acquisition by the company. (4) Cost Control or control of the company's financial condition. (5) There is a merger between two or more brands to form a new brand into a bigger brand. (6) To support the new culture that exists in the company / organization. (7) The existence of a new product made by the company

In conducting rebranding a company must design by compiling strategies so that the desired rebranding objectives can be achieved. Moran \& Muzellec (2017) when a company carries out the rebranding process must form elements that can be used as a rebrangding strategy. The four elements consist of: 1 . Repositining (forming a new position in the minds of the public) 2 . Renaming (giving the company a new name) 3. Redesigning (redesigning the company's identity) 4. Relaunching (reintroducing changes that occur through events or communication media) (Watie, 2016). 


\section{F. Brand Awareness}

Brand is the identity of a product, while awareness means awareness. Brand awareness is an awareness that the public or the public has about the brand of a product circulating in the market. According to creating brand awareness means increasing the popularity of a brand to the public with the target of obtaining introduction, knowledge and in-depth understanding of the product in order to create a positive image of the company or organization (Lailiyah, 2019).

According to Hamid (2017) The process of forming brand awareness consists of four stages, namely: 1. Unaware of brand (The stage where consumers feel they do not know or have doubts about a brand) 2. Brand recognition (at this stage consumers are able or already familiar with brand of a product when given a stimulus) 3 . Brand recal (at this stage consumers are able to remember the brand of a product without having to be given a stimulus) 4. Top of mind (As the name suggests top of mind means the brand of a product has a good impression on the mind of the consumer).

\section{Method}

In this study, researchers used a qualitative descriptive method so that the data obtained were more in-depth and more complete. According to Nawawi (2012) The descriptive-qualitative method focuses on observation and the scientific atmosphere (natural setting). Researchers go directly to the field, act as observers. He categorized behavior, observed symptoms, and he recorded them in an observation book. So that the qualitative descriptive method is a method of looking for theory, not testing the theory (Miles \& Huberman, 2012).

Qualitative descriptive research is research that is carried out by directly understanding what phenomena are being experienced by research subjects. Therefore, this research will be conducted by coming directly to PT. Indonesia Building Solutions to observe and understand how the strategies implemented by PT. Indonesia Building Solutions is in the process of rebranding it is currently doing (Nawawi, 2012).

The research object to be studied is the Rebranding Strategy of PT. Indonesia Building Solutions Plant Cilacap and this research will be conducted at PT. Indonesia Building Solutions which is located at Jl. Engineer Haji Juanda, Karangtalun, North Cilacap, Padaramai, Karangtalun, Kec. North Cilacap, Cilacap Regency, Central Java. with research time starting from January 20, 2020 to July 20, 2020.

There are several ways to collect data, namely 1 . Interview with internal or external parties of the company (Moleong, 2018). In this study, researchers conducted interviews with Public Relations or corporate communication, Community Relations manager, retail business, the surrounding community. 2. Observation by seeing and witnessing the activities carried out by the resource persons related to rebranding activities. 3. Documentation in the form of notes or photos obtained by researchers either directly or company archives. 4 . Internet which contains supporting data regarding company news. The data that has been obtained are then analyzed through several techniques, namely 1. Data collection. 2. Data reduction which is the selection and simplification of data that has been obtained in the field. 3. Presentation of data which is the process of combining and stringing linkages between data, describing the processes and phenomena obtained during research. 4 . Drawing conclusions is the development of accuracy in data units (Moleong, 2017).

The technique for maturing the analyzed data is the validation technique. In this technique, researchers use data triangulation techniques, according to Moleong (2017) data triangulation technique is a technique to check the validity of data by utilizing other things beyond the data obtained. From several data triangulation techniques, the researcher chose source triangulation by comparing the observed data with the interview data, whether the results of the interviews with the main informants were the same as the results of other informant interviews. From the results of this comparison, the same views and thoughts will be obtained so that the data obtained can be said to be valid because there are similarities from various sources. 


\section{Results and Discussion}

Based on the results of research that has been conducted, in January 2019 the Semen Indonesia Group (SIG) purchased shares and acquired PT. Holcim Tbk Cilacap, which is part of Holcimlafarge, has a share ownership of $80.6 \%$. The acquisition led to an agreement between the two parties to no longer use the name Holcim as their identity. Holcimlafarge gives a period of one year for new shareholders to change the name of Holcim from the company's identity, if it exceeds the specified time period, the company must pay a royalty of $5 \%$ of total turnover. Therefore, SIG management agreed to change the brand name to PT. Indonesia Building Solutions and dynamix as the name of the product. After having a new name to be launched, the company determines what steps will be taken to introduce its new brand because it is right on target (Prayunantyo \& Supriono, 2017).

Stakeholders mapping is the first action the company takes before compiling a rebranding strategy. The alignment is done by classifying who is the target or target of this rebranding process. Stakeholders mapping consists of several groups from various layers who have a relationship or influence on development of the company. In the process, PT. SBI classifies stakeholders based on 6 categories, including:

\begin{tabular}{|c|c|c|c|}
\hline \multirow{2}{*}{ No } & \multicolumn{3}{|c|}{ Stakeholders Mapping PT. SBI } \\
\hline & Category & Segmentation & Function \\
\hline 1. & Government & $\begin{array}{l}\text { Central and } \\
\text { local } \\
\text { governments, } \\
\text { forestry } \\
\text { services, etc. }\end{array}$ & $\begin{array}{l}\text { Have } \\
\text { interests } \\
\text { related to } \\
\text { company } \\
\text { establish } \\
\text { ment } \\
\text { permits } \\
\text { and } \\
\text { mining } \\
\text { permits } \\
\text { in } \\
\text { Nusakam } \\
\text { bangan. }\end{array}$ \\
\hline 2. & $\begin{array}{l}\text { Business } \\
\text { partner }\end{array}$ & $\begin{array}{l}\text { Distributors, } \\
\text { retail } \\
\text { businesses, } \\
\text { contractors, } \\
\text { construction } \\
\text { workers }\end{array}$ & $\begin{array}{l}\text { Helping } \\
\text { compani } \\
\text { es in } \\
\text { increasin } \\
\text { g sales of } \\
\text { their } \\
\text { products } \\
\text { to a } \\
\text { wider } \\
\text { range }\end{array}$ \\
\hline 3. & Community & $\begin{array}{l}\text { Community } \\
\text { leaders, } \\
\text { religious } \\
\text { leaders, youth }\end{array}$ & $\begin{array}{l}\text { Helping } \\
\text { compani } \\
\text { es } \\
\text { convey }\end{array}$ \\
\hline
\end{tabular}




\begin{tabular}{|l|l|l|l|}
\hline & & $\begin{array}{l}\text { leaders, NGOs, } \\
\text { the general } \\
\text { public around } \\
\text { the company }\end{array}$ & $\begin{array}{l}\text { informati } \\
\text { on } \\
\text { goals to } \\
\text { the } \\
\text { public to } \\
\text { be heard } \\
\text { more. }\end{array}$ \\
\hline 4. & Media & $\begin{array}{l}\text { Harian jogja, } \\
\text { Radar } \\
\text { banyumas, } \\
\text { jawa pos, dll }\end{array}$ & $\begin{array}{l}\text { Agencies } \\
\text { that help } \\
\text { compani } \\
\text { es } \\
\text { dissemin } \\
\text { ate } \\
\text { informati } \\
\text { on to the } \\
\text { public }\end{array}$ \\
\hline 5. & Employees & $\begin{array}{l}\text { All workers at } \\
\text { PT. Solutions } \\
\text { to Build } \\
\text { Indonesia }\end{array}$ & $\begin{array}{l}\text { Increase } \\
\text { company } \\
\text { productiv } \\
\text { ity }\end{array}$ \\
\hline 6. & Students & $\begin{array}{l}\text { Elementary } \\
\text { School, Junior } \\
\text { High School, } \\
\text { Senior High } \\
\text { School, and } \\
\text { students } \\
\text { collage }\end{array}$ & $\begin{array}{l}\text { Establish } \\
\text { a good } \\
\text { image of } \\
\text { the } \\
\text { company } \\
\text { in all } \\
\text { groups, } \\
\text { including } \\
\text { students. }\end{array}$ \\
\hline
\end{tabular}

Table 1. source: processed by researchers

After determining the stakeholder mapping, then the company determines how to convey information on changes that have occurred to each category. There are various programs carried out by PT. Solutions Bangun Indonesia as a form of strategy, such as:

\section{Government}

Before implementing its rebranding strategy, the company must first carry out permits through official letters according to government procedures. PT. Indonesia Building Solutions also made presentations by top management directly / head to head to the central government regarding the sustainability of the company (Harlie, 2010).

For the central government, the strategy is not too complicated because in addition to being a state-owned company, the establishment of PT. Indonesia Building Solutions also assists the government in improving people's welfare through its various Corporate Social Responsibility programs.

As for the cilacap local government, apart from helping the community's welfare, PT. Indonesia Building Solutions carries out a strategy by being supportive in regional activities. One of them is in 
the car free day program conducted by Cilacap district, PT. Indonesia Building Solutions became a sponsorship at the event.

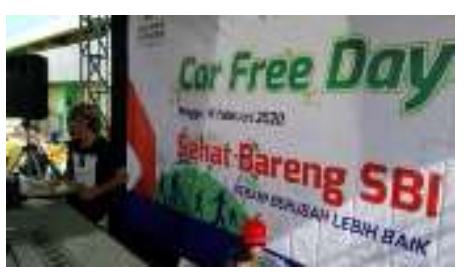

Fig. 1.Source: company archives

\section{Business Partners}

For retail businesses, distributors, and corporate contractors to hold gatherings. The gathering was held so that information related to company rebranding could be conveyed properly so that unwanted bad perceptions did not occur (Campbell \& Hale, 2018).

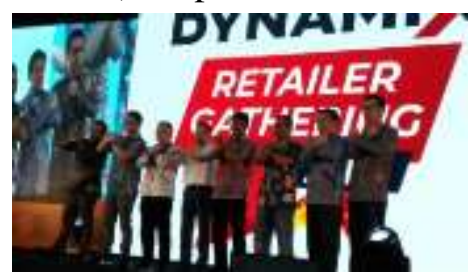

Fig. 2. Source: company archives

Even though they do not have a direct business relationship, a builder acts as a person who can influence the people who employ him to choose dynamix cement when doing construction. Therefore, PT. Indonesia Building Solutions uses builders as one of its segments through training programs.

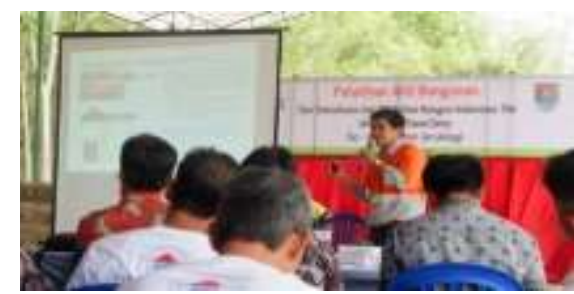

Fig. 3. Source: company archives

\section{Community}

Community is an important part of the company so that it can continue to operate with community support. In community segmentation, the company always informs about the rebranding that is being carried out through regular meetings with NGOs, companies like to often participate in activities of the surrounding community (Newman, 2004).

\section{Media}

For the media category of PT. Indonesia Building Solutions is pursuing a strategy by maintaining good relations with the media to reduce negative news. What is done to maintain good relations is by holding regular media gatherings. Besides that, PT. Indonesia Building Solutions also collaborates with the jogja daily media to create talk shows for students. 
Fig. 4. Source: company archives

\section{Employees}

Employees have a big role in the progress of the company. To increase employee loyalty to the company, PT. Indonesia Building Solutions provides its employees with excellent facilities.

In addition to facilities, companies also often conduct family gatherings for employees and their families to establish a good relationship between employees' families (De Jong \& Den Hartog, 2007).

\section{Students}

Students who are the segmentation of PT. Indonesia Building Solutions is a student from elementary to high school in Cilacap area. However, the company also opens learning opportunities for students all over Indonesia to come and visit the factory.

This was done so that PT. Indonesia Building Solutions can shape the company's good image to the younger generation. So that brand awareness that is being formed can be accepted in all circles.

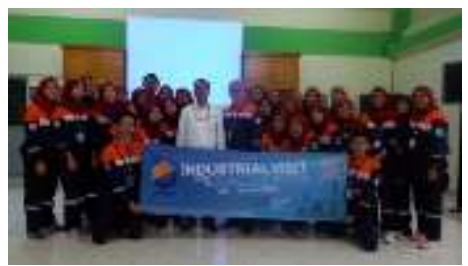

Fig. 5. Source: company archives

In these programs PT. Indonesia Building Solutions provides all the information related to this rebranding. The informed changes in identity include:

\begin{tabular}{|c|c|c|c|}
\hline \multirow{2}{*}{ No } & \multicolumn{3}{|c|}{ Rebranding Identity PT. SBI } \\
\hline & Before & Indikator & After \\
\hline 1 & $\begin{array}{c}\text { PT. Holcim } \\
\text { Plant } \\
\text { Cilacap }\end{array}$ & $\begin{array}{l}\text { Brand } \\
\text { merk }\end{array}$ & $\begin{array}{l}\text { PT. Indonesia } \\
\text { Building } \\
\text { Solutions } \\
\text { Plant Cilacap }\end{array}$ \\
\hline 2 & Holcim & Logo & $\begin{array}{l}\text { SOUSIEANGUN } \\
\text { INDONESIA }\end{array}$ \\
\hline 3. & Red & Color & $\begin{array}{l}\text { Green } \\
\text { (company that } \\
\text { cares about } \\
\text { the } \\
\text { environment) } \\
\text { and gray } \\
\text { (describes the } \\
\text { color of the } \\
\text { product being } \\
\text { sold) }\end{array}$ \\
\hline
\end{tabular}




\begin{tabular}{|c|c|c|c|}
\hline \multirow{2}{*}{ No } & \multicolumn{3}{|c|}{ Rebranding Identity PT. SBI } \\
\hline & Before & Indikator & After \\
\hline 4. & $\begin{array}{l}\text { "Building } \\
\text { Together" }\end{array}$ & Tagline & $\begin{array}{l}\text { "Dare to } \\
\text { Change for } \\
\text { the Better" }\end{array}$ \\
\hline 5. & $\begin{array}{l}\text { Industrial } \\
\text { company } \\
\text { that } \\
\text { produces } \\
\text { cement and } \\
\text { clinker }\end{array}$ & $\begin{array}{l}\text { Business } \\
\text { unit }\end{array}$ & $\begin{array}{l}\text { Industrial } \\
\text { companies } \\
\text { that produce } \\
\text { cement, } \\
\text { clinker, and } \\
\text { also } \\
\text { "nathabumi" } \\
\text { waste } \\
\text { treatment } \\
\text { services }\end{array}$ \\
\hline 6 & & $\begin{array}{l}\text { Brand } \\
\text { produk }\end{array}$ & \\
\hline 7 & $\begin{array}{l}\text { Foreign } \\
\text { Products }\end{array}$ & $\begin{array}{l}\text { Positionin } \\
g\end{array}$ & $\begin{array}{l}\text { Indonesian- } \\
\text { owned } \\
\text { products with } \\
\text { the same } \\
\text { quality }\end{array}$ \\
\hline
\end{tabular}

Table 2. source: processed by researchers

With the change in identity, it also has an impact on changes to the company's campaign or advertisement. While still being Holcim, the company's campaign invited the community to jointly carry out development using Holcim cement using the tagline "Building Together with Holcim". When he became PT. Indonesia Building Solutions has two campaigns built, product campaigns are more prominent to product quality that remains the same, while brand campaigns are more prominent repositioning of companies that have become state-owned companies (Indonesia). The new company campaign follows the new tagline change, which is "Dare to Change for the Better"

The rebranding is carried out using strategies that have been prepared by the corporate communication team and the team. The process is carried out by following the rebranding stages, as follows:

\section{Repositioning}

Positioning is the impression that is in the public's mind of a company or organization. repositioning often involves changing product identities, linking existing competitors and changing the company's image in the minds of consumers. A company or organization must be able to position itself to achieve the vision and mission made by the company or organization. According to Tzabbar (2009) Repositioning can also be interpreted as an effort to reposition a brand or product that has been embedded in the minds of the community. 
Repositioning is carried out with the aim of confirming a product in order to survive. Positioning created by PT. Indonesia Building Solutions, namely "State Owned Company (Indonesia)". This positioning seeks to make the stakeholders feel proud of this company because they have the courage to take over the power of foreign companies that take natural resources in Indonesia. Repositioning conducted by PT. Indonesia Building Solutions is the starting point in determining the next steps for change. Like the company's tagline, "Dare to Change Better", PT. Indonesia Building Solutions makes sentences based on company repositioning that describe the condition of a company that dares to make big decisions while maintaining the best quality (Jourdan, Bureau, Rochais, \& Dallemagne, 2020).

\section{Renaming}

Name becomes the main identity for a place, a person, even a company. For a company, the name can also be called a brand or brand that will differentiate the company from other similar companies. According to Ellison, Mason, \& Scior (2015) states that renaming is an important thing because brand names play an important role as the face or early indicator of a brand. After determining the new brand that will be used as the company name, PT. Indonesia Building Solutions then replaced all company attributes that still used the old brand name.

After the acquisition process, the company launched a new name, namely PT. Indonesia Building Solutions, whose name will later become a brand as well as a brand for this company. The naming is in accordance with the company's vision, which is to become the largest provider of building material solutions in the region. Not only did it bring up a new brand name, in this transition process PT. Indonesia Building Solutions also carries a new name for its products, namely dynamix. This was done because the name of the product that used to be had the same as the old brand name, so the company finally came up with the name of the new product. Efforts made by PT. Indonesia Building Solution in the renaming process, namely: changing company uniforms, ID cards, company email, etc (Lieberman \& First, 2007).

\section{Redesaigning}

Redesaigning is a process of changing graphic elements consisting of colors and shapes. A logo change is usually followed by a change in the meaning or philosophy of the image. According to Hendrayani \& Manihuruk (2020) say that redesigning is a change where the design of tangible and other visual elements, such as logos, advertisements, office stationery, merchandise, and customized interior and exterior with the new desaign concept.

Redesaigning conducted by PT. Indonesia Building solution is to change the overall logo design. Starting from the basic color, namely gray which symbolizes the color of cement as the product produced, and the green color symbolizes the company that is responsible for greening. In the logo there is also the inscription of PT. Indonesia Building Solutions as a sign that the shape of the image is a picture of PT. Indonesia Building Solutions.

\section{Relaunching}

Relaunching is the last stage in a rebranding process. Relaunching the brand is an act of relaunching a new brand that has undergone a change from the old brand. According to Milleur \& Desveaux (2020) said that relaunching determines how stakeholders see the new brand that will be introduced, namely by publishing a new brand, which is the final stage that determines how the wider community (employees, customers, investors, and journalists) might perceive a new name (Townsend \& Hocking, 2019).

In the relaunching stage, PT. Indonesia Building Solutions carries out the strategies they have designed through programs and communication media. Relaunching is carried out based on two stages, namely internal and external, each stage of course also through different ways. Internal launching was carried out by holding a top management gathering in September 2019.

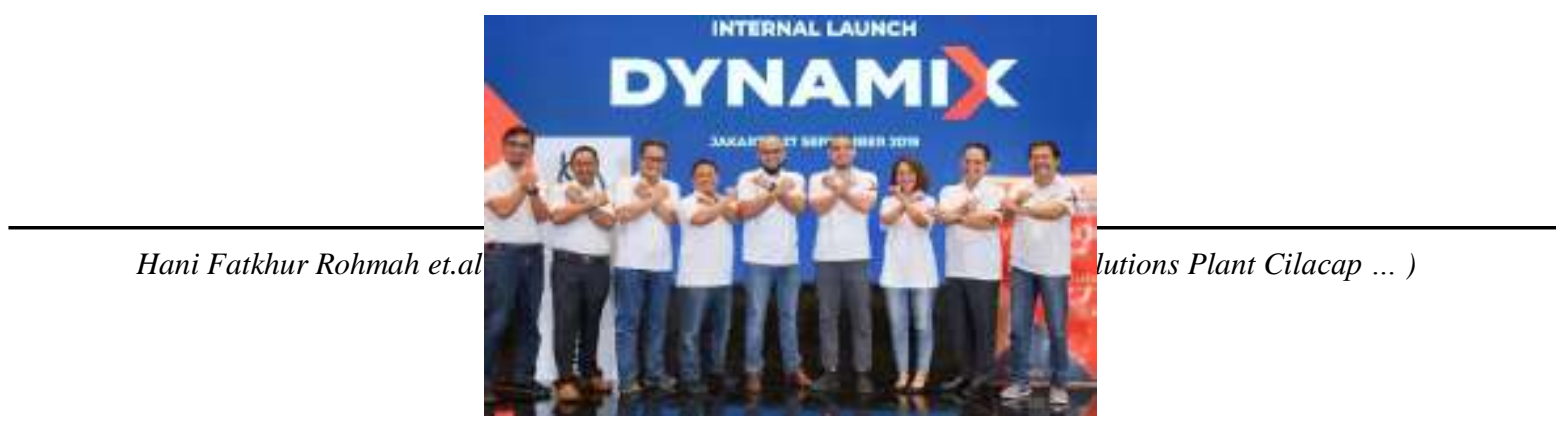


Fig. 6. Relaunching Internal

The external launching was carried out by building a monument located on Jalan Damar, Karangtalun, Cilacap. The position of the monument is very strategic, which is in the middle of a crossroads, so it really attracts the attention of passing motorists.

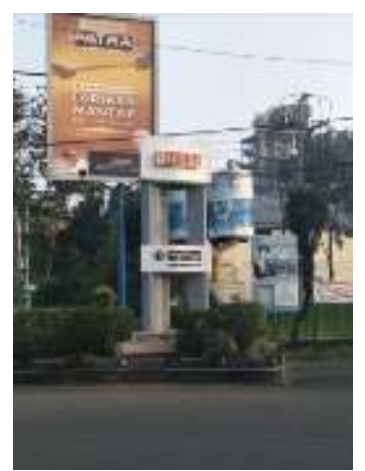

Fig. 7. Relaunching external

Every company that makes the transition and designs rebranding strategies certainly has a specific goal. Creating brand awareness of new brands is one of them. As was done by PT. Indonesia Building Solutions, established for more than 15 years as Holcim and has been widely recognized by the public, the company has the goal of building brand awareness by implementing several strategies that are deemed appropriate. Based on the existing theory, the process of building brand awareness will occur in 4 stages. The following data were found by researchers in the research process:

The stage of doubt about a new brand that has an impact on the decision to buy a product (Unaware of Brand)

The occurrence of a rebranding can certainly have an impact on consumer doubts about a new brand. The existence of designing rebranding strategies can reduce consumer doubts about new brands.

In the rebranding process conducted by PT. Indonesia Building Solutions, of course, is also experiencing an unaware of brand stage. There are several business partners owned by PT. Indonesia Building Solutions has doubts about the decline in product quality as a result of the acquisition. This form of doubt caused several retail businesses and distributors to reduce the number of product purchases. This doubt arose due to a lot of news about the declining turnover of the Indonesian cement group due to buying Holcim shares, besides that when the news of the acquisition appeared, the company did not have a new brand name and had not yet implemented a strategy. rebranding strategy.

The stage where consumers begin to recognize a new brand (Brand Recognition)

The brand recognition stage is the stage where consumers get to know a new brand. At this stage, consumer perceptions begin to emerge about the brand. If consumers have good perceptions, there will be confidence in the quality of the product, if consumers have bad perceptions it will reduce their interest in choosing the product.

Through the application of a rebranding strategy based on stakeholder groupings, PT. Indonesia Building Solutions can reduce doubts or bad consumer perceptions of product quality. In the retail ghatering program, PT. Indonesia Building Solutions tries to build repositioning of state-owned 
companies to business partners by ensuring that even though it has been taken over by Indonesia, the cement produced still has the same product quality. In addition, giving stimulus to consumers is also done so that consumers get to know new brands. The stimulus of "Holcim turns to dynamix" is always present in the company's advertising process.

Of the four stages of brand awareness, PT. Indonesia Building Solutions has only reached the second stage, namely the brand recognition stage. PT. Indonesia Building Solutions has only entered its second stage because consumers are only starting to get to know the company's new brand but have not been able to remember it without being given a stimulus. Evidenced by the product packaging used by the company, PT. Indonesia Building Solutions added the phrase "Holcim changed to dynamix"

\section{Conclusion}

After processing and presenting the data that researchers have obtained from the research process at PT. Indonesia Building Solutions Plant can be concluded that the strategy carried out by the company is to classify first who is the stakeholder and how it affects the sustainability of PT. Indonesia Building Solutions. With the formation of stakeholder mapping, corporate communication of PT. Indonesia Building Solutions to determine how to effectively convey rebranding information.

Starting from February 2020 PT. Indonesia Building Solutions has successfully rebranded itself by replacing the old brand to the new brand altogether. This change was marked by the change of company name (PT. Indonesia Building Solutions), product name (Dynamix), tagline, logo, and the addition of business units. This change was followed by changes in corporate identity such as ID cards, name signs, company e-mails, uniforms, stickers in vehicles, and the construction of a PT. SBI which marks the inauguration of the rebranding of PT. Indonesia Building Solutions.

With the concluded results, there are several suggestions given by the researcher. The introduction of two new names that differ between the brand name and the product should be done simultaneously to make it more efficient, for example in advertisements or new product packaging the company should raise the name PT. Indonesia Building Solutions also so that the company's brand can be recognized by the wider public. In addition, in determining a rebranding strategy for business partners, it is better if the local marketing team is involved, because the marketing team is more often in touch with business partners so that the strategies formulated can be more precise.

All of the rebranding strategies designed have been $100 \%$ implemented. Even so, PT. Indonesia Building Solutions must continue to promote and socialize more intensively and more actively through various activities and various communication media both digital and conventional in order to create brand awareness of new brands and be able to become top of mind brands.

\section{Acknowledgment}

Praise be to Allah SWT who has bestowed his grace so that I was able to complete the research entitled "Rebranding Strategy of PT. Indonesia Building Solutions Plant Cilacap in Forming Brand Awareness ". The author understands that without help, prayer, this research guidance cannot be completed properly. Therefore, the researcher would like to thanks: Mr. Choirul fajri, S.I.Kom., M.A. who have provided guidance so that this research can be completed, Mr. Deny Nuryandain and Mr. Kusdiharta, and other sources who have been willing to provide the data and information I need, My parents and siblings always provide support and motivation, Myself who has been able to complete this research. Hopefully this research can be useful and add insight in the field of communication, especially regarding rebranding for researchers and readers.

\section{References}

Brenner, J. E., \& Igamberdiev, A. U. (2021). Communication. In Studies in Applied Philosophy, Epistemology and Rational Ethics. https://doi.org/10.1007/978-3-030-62757-7_12

Campbell, D., \& Hale, R. (2018). Implications for the professional. In Working in the Dark. https://doi.org/10.4324/9781315731490-10 
Cangara, H. (2002). Pengantar Ilmu Komunikasi (Cetakan Keempat). In Jakarta: PT Rajagrafindo Persada.

Collange, V. (2015). Consumer reaction to service rebranding. Journal of Retailing and Consumer Services. https://doi.org/10.1016/j.jretconser.2014.07.003

Davis, W. S., Yen, D. C., Yen, D. C., \& Davis, W. S. (2020). Rapid application development (RAD). In The Information System Consultant's Handbook. https://doi.org/10.1201/9781420049107-32

De Jong, J. P. J., \& Den Hartog, D. N. (2007). How leaders influence employees' innovative behaviour. European Journal of Innovation Management. https://doi.org/10.1108/14601060710720546

Ellison, N., Mason, O., \& Scior, K. (2015). Renaming schizophrenia to reduce stigma: Comparison with the case of bipolar disorder. British Journal of Psychiatry. https://doi.org/10.1192/bjp.bp.114.146217

Hamid, S. (2017). Jurnal Manajemen \& Bisnis Kreatif. Jurnal Manajemen Bisnis.

Harlie, M. (2010). Pengaruh Disiplin Kerja, Motivasi dan Pengembangan Karier Terhadap Kinerja Pegawai Negeri Sipil Pada Pemerintah Kabupaten Tabalong di Tanjung Kalimantan Selatan. Jurnal Manajemen Dan Akuntansi.

Hendrayani, Y., \& Manihuruk, H. (2020). REDESAIN KEMASAN DALAM MENINGKATKAN BRAND AWARNESS PRODUK UNGGULAN UKM CILODONG BERKARYA. Jurnal Bakti Masyarakat Indonesia. https://doi.org/10.24912/jbmi.v3i1.8338

Iannuzzi, P. (2000). Information literacy competency standards for higher education. Community and Junior College Libraries. https://doi.org/10.1300/J107v09n04_09

Jourdan, J. P., Bureau, R., Rochais, C., \& Dallemagne, P. (2020). Drug repositioning: a brief overview. Journal of Pharmacy and Pharmacology. https://doi.org/10.1111/jphp.13273

Korkmaz Özcan, Z. (2016). The actor's point of view in terms of governance tendency to the health tourism: The case of Antalya $<\mathrm{P}>$ Yönetişim eğilimleri çerçevesinde sağlı turizmine aktörlerin bakış açısı: Antalya örneği. Journal of Human Sciences. https://doi.org/10.14687/jhs.v13i2.3936

Kotler, P., \& Keller, K. L. (2016). Marketing Mangement. In Pearson Edition Limited.

Kotler Philip. (2002). Kotler on... In Manajemen Pemasaran.

Lailiyah, N. (2019). Analisis Kegiatan Public Relation Untuk Membangun Brand Awerness di PT Victory International Futures. Jurnal Studi Manajemen Dan Bisnis. https://doi.org/10.21107/jsmb.v6i2.6685

Lieberman, J. A., \& First, M. B. (2007). Renaming schizophrenia. British Medical Journal. https://doi.org/10.1136/bmj.39057.662373.80

Miles, M. B., \& Huberman, M. A. (2012). Analisis Data Kualitatif: Buku Sumber Tentang Metode-Metode Baru. In Universitas Indonesia_UI Press.

Milleur, Y., \& Desveaux, J. B. (2020). Getting back to work. Topique. https://doi.org/10.3917/top.148.0063

Mishra, K., Boynton, L., \& Mishra, A. (2014). Driving Employee Engagement: The Expanded Role of Internal Communications. International Journal of Business Communication. https://doi.org/10.1177/2329488414525399

Moleong, L. J. (2017). Metodologi Penelitian Kualitatif (Edisi Revisi). In PT. Remaja Rosda Karya.

Moleong, L. J. (2018). Metodologi Penelitian Kualitatif, cet. In XI. Bandung: PT Remaja Rosdakarya.

Moran, G., \& Muzellec, L. (2017). eWOM credibility on social networking sites: A framework. Journal of Marketing Communications. https://doi.org/10.1080/13527266.2014.969756

Nawawi, I. (2012). Metoda Penelitian Kualitatif. CV Dwiputra Pustaka Jaya, Jakarta.

Newman, M. E. J. (2004). Detecting community structure in networks. European Physical Journal B. https://doi.org/10.1140/epjb/e2004-00124-y

Nulhusna, R., Sandhyaduhita, P. I., Hidayanto, A. N., \& Phusavat, K. (2017). The relation of e-government quality on public trust and its impact on public participation. Transforming Government: People, Process and Policy. https://doi.org/10.1108/TG-01-2017-0004 
Nunan, D., \& Di Domenico, M. L. (2019). Older Consumers, Digital Marketing, and Public Policy: A Review and Research Agenda. Journal of Public Policy and Marketing. https://doi.org/10.1177/0743915619858939

Peluso, É. de T. P., \& Blay, S. L. (2009). Public stigma in relation to individuals with depression. Journal of Affective Disorders. https://doi.org/10.1016/j.jad.2008.08.013

Prayunantyo, B., \& Supriono, S. (2017). ANALISIS STRATEGI PEMBELIAN DALAM UPAYA PENGADAAN PART MATERIAL IMPORT (Studi pada PT. Indonesia Nippon Seiki). Jurnal Administrasi Bisnis.

Rahman, M., \& Lambkin, M. (2015). Creating or destroying value through mergers and acquisitions: A marketing perspective. Industrial Marketing Management. https://doi.org/10.1016/j.indmarman.2015.01.003

Thibodeau, C. T., Hertig, C. A., \& Barnett, G. A. (2010). Public relations. In The Professional Protection Officer. https://doi.org/10.1016/B978-1-85617-746-7.00042-0

Tjiptono, \& Fandy. (2015). Strategi Pemasaran. In Yogyakarta: Andi.

Townsend, E., \& Hocking, C. (2019). Relaunching teaching occupation. Journal of Occupational Science. https://doi.org/10.1080/14427591.2018.1541698

Trott, O., \& Olson, A. J. (2009). AutoDock Vina: Improving the speed and accuracy of docking with a new scoring function, efficient optimization, and multithreading. Journal of Computational Chemistry. https://doi.org/10.1002/jcc.21334

Tzabbar, D. (2009). When does scientist recruitment affect technological repositioning? Academy of Management Journal. https://doi.org/10.5465/AMJ.2009.44632853

Ulitsky, I., Shkumatava, A., Jan, C. H., Sive, H., \& Bartel, D. P. (2011). Conserved function of lincRNAs in vertebrate embryonic development despite rapid sequence evolution. Cell. https://doi.org/10.1016/j.cell.2011.11.055

Walker, A. (1985). Public relations bibliography: Thirteenth edition 1984. Public Relations Review. https://doi.org/10.1016/S0363-8111(85)80052-7

Watie, E. D. S. (2016). Komunikasi dan Media Sosial (Communications and Social Media). Jurnal The Messenger. https://doi.org/10.26623/themessenger.v3i2.270 